\title{
Présentation de Richard Millet
}

Jean-Yves Laurichesse

\section{(2) OpenEdition}

Journals

Édition électronique

URL : https://journals.openedition.org/ccs/458

DOI : $10.4000 /$ ccs. 458

ISSN : 2558-782X

\section{Éditeur :}

Presses universitaires de Rennes, Association des lecteurs de Claude Simon

\section{Édition imprimée}

Date de publication : 30 juin 2005

Pagination : 135-137

ISBN : 2914518676

ISSN : $1774-9425$

\section{Référence électronique}

Jean-Yves Laurichesse, «Présentation de Richard Millet », Cahiers Claude Simon [En ligne], 1 | 2005, mis en ligne le 20 septembre 2017, consulté le 02 mars 2022. URL : http://journals.openedition.org/ ccs/458; DOI : https://doi.org/10.4000/ccs.458 
Paroles d'écrivains 

Richard Millet est né à Viam (Corrèze) en 1953, a passé une partie de son enfance au Liban, vit à Paris. Il construit depuis une vingtaine d'années une ouvre exigeante : romans, nouvelles, mais aussi essais personnels tel Le Sentiment de la langue 1 , " mélange " plusieurs fois complété et remanié de textes brefs sur la langue, la littérature, la musique. Ses premiers récits, étranges, tendus, sont marqués par la lecture de Louis-René des Forêts et de Maurice Blanchot, avec en particulier la "petite trilogie noire " que constituent L'Angélus (1988), La Chambre d'ivoire (1989) et L'Écrivain Sirieix (1992). Avec La Gloire des Pythre (1995), puis L'Amour des trois sours Piale (1997), l'écriture s'oriente vers une forme romanesque ample, polyphonique, portée par un phrasé envoûtant. Richard Millet invente autour de son village natal, rebaptisé Siom, un territoire à la fois mémoriel et imaginaire, que les romans suivants confronteront à d'autres espaces : la banlieue parisienne (Lauve le pur, 2000), le Canada (La Voix d'alto, 2001). Dans son dernier roman publié, $M a$ vie parmi les ombres (2003), somptueuse archéologie d'une enfance et d'une famille, il rassemble le monde de Siom tout en paraissant s'approcher davantage de son histoire personnelle ${ }^{2}$. Admirateur de Dostoïevski, de Proust, de Faulkner, Richard Millet l'est aussi de Claude Simon, dont il cite par exemple, dans un texte ajouté à la dernière réédition du Sentiment de la langue, un extrait des Géorgiques comme parfait exemple de " texte poétique " ${ }^{3}$. Il a bien voulu nous parler de sa lecture tout en évoquant aussi - car les deux sont indissociables pour un écrivain - son propre travail.

$$
\text { J.-Y. L. }
$$

\footnotetext{
${ }^{1}$ Dernière édition " revue et augmentée ", La Table Ronde, 2003. Prix de l'Essai de l'Académie française en 1994.

${ }^{2}$ Les romans de Richard Millet sont publiés chez P.O.L., puis chez Gallimard à partir de La Voix d'alto. Ils sont repris en collection Folio.

3 "Amoureuse défiance envers la poésie ", in Le Sentiment de la langue, pp. 266-267.
} 